\title{
Entäs aikuiset? \\ - Katsaus medialukutaidon edistämiseen digitalisoituvassa Suomessa
}

\author{
$+y$ \\ Digitalisaatio on nimetty hallituksen strategiaa \\ läpileikkaavaksi teemaksi, mikä kasvattaa odotuksia \\ kansalaisten medialukutaidosta. Lasten ja nuorten \\ mediakasvatuksen lisäksi myös aikuisten \\ mediataitoja tulisi edistää.
}

KANSALAISTEN MEDIALUKUTAIDON tarve on viime aikoina ollut otsikoissa monin tavoin. Sotilaalliset konfliktit ja niihin liittyvä propaganda erityisesti sosiaalisessa mediassa ovat nostaneet informaatiosodankäynnin ja viestien totuudellisuuden arvioimisen säännöllisesti esiin. Pienimuotoista kuohuntaa aiheuttaa itseään vaihtoehtomediaksi kutsuva MV-lehti -sivusto. Useat viestimet ovat nostaneet esiin sivuston epäluotettavuuden ja asiattomuuden. Tästä huolimatta - tai sen vuoksi sivusto on kerännyt Facebook-tililleen yli 43000 tykkääjää, mikä on huomattavasti enemmän kuin suurilla alueellisilla uutismedioilla, esimerkiksi Aamulehdellä tai Turun Sanomilla. Kriittisen tulkinnan lisäksi mediassa ja median avulla toimimisen taitoja tarvitaan yhä enemmän.
Keväällä 2015 aloittanut Suomen hallitus uskoo digitalisaation ratkaisevan useita valtion ongelmia ja palveluiden digitaalisuuteen aiotaan panostaa tällä hallituskaudella. Digitalisaatio on nimetty hallituksen strategiaa läpileikkaavaksi teemaksi. Hallitusohjelman "kärkihankkeisiin” kuuluu peruskoulutuksen uudistaminen digitaalisten oppimisympäristöjen avulla. Näihin tavoitteisiin on kytketty myös pedagogiikan uudistaminen. Hanke tähtää oppimistulosten parantamiseen ja erojen kaventamiseen. Sillä nähdään vastattavan "kehityksen haasteisiin" ja tuotettavan "tulevaisuuden taitopohjaa". (Ratkaisujen Suomi 2015.) Hallitus ei ole yksin näkemyksensä kanssa, vaan kansalaisten digitaalinen lukutaito on tärkeä osa muun muassa Euroopan digitaalistrategiaa (2010). 
Akateemisesti medialukutaidon määritelmästä ei ole yksimielisyyttä kansallisesti eikä kansainvälisesti (Kynäslahti, Kupiainen \& Lehtonen 2007; Potter 2010; Potter 2013; Martens 2010). Euroopan komission mukaan medialukutaito koskee kaikkia medioita ja liittyy "taitoon käyttää tiedotusvälineitä, ymmärtää ja arvioida kriittisesti tiedotusvälineiden ja mediasisältöjen eri puolia sekä viestiä erilaisissa yhteyksissä”. Viestimiseen kuuluu myös omien mediasisältöjen luominen. (Euroopan komission suositus 2009.) Suomessa ja suomalaisissa linjauksissa medialukutaitoa on tavattu tarkastella laaja-alaisesti (Hyvä medialukutaito 2013). Medialukutaitoa (media literacy) voidaan kuvata myös sivistyksellisenä osaamisena, mediasivistyksenä (Varis 2002). Tässä tekstissä käsitämme medialukutaidon laaja-alaisena, sivistyksellisenä sekä kulttuuris-sosiaalisena lukutaitojen kokonaisuutena.

Luomme näkökulmassa tiiviin katsauksen suomalaiseen mediakasvatuksen edistämiseen ja erityisesti sellaisiin opetus- ja kulttuuriministeriön (OKM) kansallisiin linjauksiin, joissa tuodaan esiin medialukutaidon osaamistavoitteita ja osaamisen kehittämisen keinoja. Vaikka valtaosa linjauksista suuntaa lapsiin ja nuoriin kohdistuvia mediakasvatustoimenpiteitä, niistä on luettavissa, millaisia taitoja, osaamista ja asenteita linjausten laatijat pyrkivät yhteiskunnassa tai yksittäisten kansalaisten osalta kehittämään. Lapsiin kohdistettavat toimenpiteet nimittäin tapaavat heijastaa lasten ihanteellista roolia tulevaisuuden aikuisina. Katsauksemme perusteella kansalaisten medialukutaidolle asetetaan runsaasti odotuksia niin työelämätaitojen kuin yhteiskunnallisen osallisuuden näkökulmista.

Pikainenkin katsaus kansallisiin linjauksiin kertoo, ettälasten ja nuorten medialukutaidon kehittämistä tulisi tehdä laajasti koulutus-, nuoriso- ja kulttuurisektoreilla. Systemaattisia suunnitelmia aikuisten kompetenssien edistämiseksi tai tukemiseksi on vähän, vaikka mediataidot esitellään välttämättöminä nykyajan taitoina. Lisäksi keväällä 2015 aloittaneen hallituksen on tarkoitus väljentää kuntien velvoitteita mm. kirjastopalveluiden ja vapaan sivistystyön järjestämisessä (Ratkaisujen Suomi 2015). Tämä herättää huolta aikuisten omaehtoisen sivistymisen palveluiden toteuttamisesta.
Tarkastellaanpa medialukutaitoa sitten työllisyyden ja tuottavuuden tai kansalaisten osallistumis-, vaikuttamis- ja itseilmaisumahdollisuuksien kannalta, on syytä pohtia aikuisten asemaa. Kuinka koko väestölle tarjotaan mahdollisuuksia ja tukea digitaalisessa yhteiskunnassa ja mediaympäristöissä toimimiseen tarvittavien taitojen kehittämiseksi? Sekä elinikäisen oppimisen että valtiontalouden näkökulmista on kestämätöntä, jos osaamisen kehittymistä tuetaan vain lasten ja nuorten osalta.

\section{MEDIAKASVATUKSEN EDISTÄMINEN SUOMESSA}

Kansainvälisissä vertailuissa Suomi on näyttäytynyt medialukutaidon ja sen edistämiseen tähtäävän mediakasvatuksen "mallioppilaana" erityisesti siinä, kuinka kattavasti mediakasvatus on huomioitu kansallisesti (Dunas 2013; Celot 2009). Vaikka suomalaisen mediakasvatuksen historia on vasta noin viisikymmenvuotinen, mediakasvatus, aikanaan joukkotiedotuskasvatuksen nimellä, otettiin perusopetuksen opetussuunnitelmiin jo 1970-luvun alussa (Kupiainen, Sintonen \& Suoranta 2007). Mediakasvatus tuli normittavasti osaksi myös esiopetusta vuonna 2014, kun Opetushallitus laati ensimmäisen kerran koulutuksen järjestäjiä velvoittavat esiopetuksen opetussuunnitelman perusteet.

Toisella asteella lukion opetussuunnitelman perusteet (2003) sisältävät viestintä- ja mediaosaamisen aihekokonaisuuden. Ammatillisessa koulutuksessa mediataidot on sijoitettu osaksi kaikille yhteisiä viestinnän ja vuorovaikutuksen sekä yhteiskunnassa ja työelämässä tarvittavia opintoja. Tieto- ja viestintätekniikan käyttötaidot ja niiden hyödyntäminen ovat osa matemaattisluonnontieteellisiä opintoja. Lisäksi useilla ammatillisen koulutuksen linjoilla opiskellaan ammattispesifejä media- ja mediakasvatustaitoja.

Korkeakouluista Lapin ja Tampereen yliopistot tarjoavat mediakasvatuksen maisteriohjelmat. Lisäksi vähintään yksittäisiä mediakasvatuksen kursseja on mahdollista opiskella lukuisissa yliopistoissa ja ammattikorkeakouluissa. Humanistinen ammattikorkeakoulu on myös tarjonnut toiminnallisen mediakasvatuksen erikoistumisopintokokonaisuuden. 
Opetus- ja kulttuuriministeriö tukee mediakasvatusta ja medialukutaidon edistämistä resurssi- ja informaatio-ohjauksen sekä lainsäädännön kehittämisen keinoin. Alan kehittämistyö onkin aktiivista: pelkästään vuosina 2008-2015 OKM rahoitti pitkälti yli 200 mediakasvatuksellista valtiollista tai alueellista kehittämishanketta (Palsa, Pääärvi, Tossavainen \& Pekkala 2014). Lisäksi OKMn hallinnonalalla on useita mediakasvatuksen huomioivia linjauksia ja ohjelmia, joita käsitellään tarkemmin seuraavassa luvussa. Aikuiskasvatuksen näkökulmasta merkittäviä julkisen sektorin toimijoita ovat erityisesti Opetushallitus sekä kansalaisille tarjottavien palveluiden osalta kirjastot, jotka ovat olleet aktiivisia esimerkiksi informaatiolukutaidon opetuksessa (Mustikkamäki 2014). OKMn alaisuudessa toimii myös Kansallinen audiovisuaalinen instituutti KAVI, jolla on lainmukainen tehtävä edistää mediakasvatusta (laki Kansallisesta audiovisuaalisesta instituutista 2007/1434). Kansainvälisesti vertaillen on harvinaista, että mediakasvatukselle on lailla osoitettu kansallinen vastuutaho. Lisäksi Suomessa on erittäin aktiivinen kolmas sektori, ja mediakasvatusta joko pääasiallisena työnään tai osana muuta työtään edistäviä järjestöjä on huomattavan runsaasti (Lundvall \& Andersson 2012). Myös monet yritykset edistävät mediakasvatusta osana toimintaansa, ja media-alan toimijoista esimerkiksi Yle ja Sanomalehtien Liitto ovat olleet pitkään aktiivisia mediakasvatuksessa.

Käytännössä mediakasvatuksen toteuttaminen ja medialukutaidon edistäminen eivät ole toteutuneet ongelmitta. Mediakasvatuksen vakiintuminen systemaattisesti osaksi kasvatus-, opetus- ja sivistystyötä on todettu haasteeksi useissa selvityksissä ja tutkimuksissa (OKM 2013b; Mustikkamäki 2014; Kotilainen \& Sintonen 2005). Mediakasvatuksella ei koskaan ole ollut perusopetuksessa varsinaisen oppiaineen roolia. Läpäisyaineen statusta pidetään usein mediakasvatuksen monialaisen luonteen vuoksi parhaana, mutta se johtaa myös satunnaiseen ja eriarvoistavaan tilanteeseen, jos opetus perustuu yksittäisten kiinnostuneiden työntekijöiden toimintaan (Vesterinen 2011,22-23). Vaikka mediakasvatus on ollut osa opetussuunnitelmia yli 40 vuotta, vasta tuoreimmissa opetussuunnitelman perusteissa (POPS 2014), on pyritty varmistamaan opetuksen laaja toteuttaminen kohdentamalla konkreettisesti tavoitteita oppiaineisiin. Satunnaisuus mediakasvatuksessa ei koske vain koulua. Monenlaisissa mediakasvatuksen organisaatioissa toiminnan vakiintuminen osaksi ydintehtävää on jäänyt tapahtumatta, jolloin erillisprojektien varassa tehtävä tai henkilöityvä toiminta jää usein lyhytjänteiseksi (Lundvall \& Anderson 2012; Vilmilä 2015).

Puhe aikuisten mediakasvatuksen tarpeesta ei ole uusi ilmiö. Esimerkiksi Tapio Varis (2002) herätteli vuosituhannen alussa keskustelua uusista kansalaistaidoista ja digiajan isovanhemmuudesta. Juha Suoranta (2006) peräänkuulutti jo lähes kymmenen vuotta sitten tutkimuksellista ja toiminnallista huomiota aikuisten medialukutaidolle. Hakkarainen, Hyvönen, Luksua ja Leinonen (2009) toivat niin ikään esiin ikääntyneiden osallisuuden rajoittuneisuuden suomalaisen mediakasvatuksen kentällä. Kirjoittajat peräänkuuluttivat ikääntyneille moninaisempaa toimijaroolivalikoimaa mediakasvatuksessa. Toistaiseksi aikuiskasvatus on jäänyt marginaaliin. Huomiota aikuisten varjoon jäävästä roolista tukee mm. se, että opetus- ja kulttuuriministeriön suoraan myöntämät mediakasvatuksen kehittämisavustukset on suunnattu alle 12-vuotiaiden kasvatukseen. Aikuiset ovat kyllä olleet kohderyhmänä lukuisissa kehittämishankkeissa, mutta tavoitteiden osalta välillisenä kohderyhmänä, opettelemassa paremmiksi lasten ja nuorten mediakasvattajiksi. (Palsa ym. 2014; Niinistö 2008.)

Erilaiset median käyttöä, mediakasvatusta ja medialukutaitoa tarkastelevat tutkimukset ovat nekin kohdistuneet erityisesti lapsiin ja nuoriin tai aikuisiin heidän kasvattajinansa (Pekkala, Päjärvi, Palsa, Korva \& Löfgren 2013). OKMn rahoittamista tutkimuksista esimerkkeinä voidaan mainita muun muassa lasten mediabarometrit (Suoninen 2014; 2013; Pääärvi 2012; Kotilainen 2011). Kansalaisten medialukutaidon tasosta saatiin tietoa vuonna 2009 julkaistun kansainvälisen vertailun (EAVI 2009) myötä. Vaikka tulokset olivat Suomen kannalta erittäin positiiviset, tutkimusta aikuisten medialukutaidosta selkeästi tarvitaan edelleen. 
VAIKKA MEDIAKASVATUS

MÄÄRITELMÄLLISESTI

KATTAA LINJAUKSISSA

KOKO VÄESTÖN, J $\dddot{A} \ddot{\mathrm{A}} \ddot{\mathrm{A} T}$

AIKUISET KONKREETTISTEN

TOIMENPITEIDEN OSALTA

LASTEN JA NUORTEN VARJOON.

Keväällä 2015 Nuorisotutkimusseura julkaisi mediakasvatuksen tutkimuksellista kehittämistä koskevan raportin, jossa nostetaan esiin asiantuntijoiden huoli muun muassa aikuisten mediakasvatusta koskevan tutkimuksen vähyydestä (Vilmilä 2015).

Suoranta (2006) totesi aikuisten medialukutaitoa tarkastelevassa puheenvuorossaan, että mediakasvatusta edistävä toiminta hajaantui useamman organisaation kesken. Toiminta jäsentyi osittain vuonna 2012 perustetun Mediakasvatus- ja kuvaohjelmakeskus MEKUn (nyk. Kansallisen audiovisuaalisen instituutin KAVIn yksikkö) myötä. Yleisen aikuiskasvatuksen osalta mediakasvatusviranomaisen perustaminen ei tuonut asiaan juuri muutosta, sillä KAVIn tehtäviä on jo laissa suunnattu lapsiin. Mediakasvatuksesta todetaan, että virasto "edistää mediakasvatusta, lasten mediataitoja ja lapsille turvallista mediaympäristöä sekä tiedottaa lapsia ja mediaa koskevista asioista" (laki Kansallisesta audiovisuaalisesta instituutista 2007/1434, \$2). MEKUn tehtäviä ei myöskään missään vaiheessa ole resursoitu siinä laajuudessa kuin sivistysvaliokunta viraston tehtäviä asetettaessa näki tarpeelliseksi (Sivistysvaliokunnan mietintö 2/2013), joten aikuiskasvatustoiminta mediakasvatuksessa on käytännössä rajautunut lasten kanssa työskentelevien ammattilaisten sekä kotikasvatuksen tukemiseen. Virasto tukee lisäksi eri kohderyhmiä palvelevien toimijoiden mediakasvatustoimintaa esimerkiksi järjestämällä keskustelutilaisuuksia alan kehittämiseksi. Tärkein toimijoita yhteen kokoava tapahtuma on vuosittainen Mediakasvatusfoorumi.
MEDIAKASVATUS KANSALLISISSA ASIAKIRJOISSA

Suomessa on toteutettu vuosien saatossa mediakasvatusta eri nimikkeiden alla ja erilaisin sisällöllisin painotuksin (Kupiainen ym. 2007). Merja Kauppisen tutkimuksen (2010) mukaan media on tekstiympäristönä käsitetty opetussuunnitelmien perusteissa eri tavoin eri aikoina. 1970-luvulla korostui median yhteiskunnallinen rooli, ja puhuttiin myös massaviestinnän haitoista. Vuoden 1985 perusopetuksen opetussuunnitelmassa mediateksteihin otettiin tiedostava, vaikuttava ja joukkoviestinnällinen näkökulma. Teknologisen kehittymisen myötä vuosien 1994 ja 2004 opetussuunnitelmien perusteissa korostui puolestaan media tiedonlähteenä. Median elämykselliset ja kokemukselliset ulottuvuudet nostettiin Kauppisen $(2010,223)$ mukaan esiin useilla eri vuosikymmenillä (POPS70, POPS94 ja POPS04).

Suomalainen peruskoulu on uudistuksen edessä uusien perusopetuksen opetussuunnitelmien perusteiden (POPS 2014) tullessa käytäntöön syksystä 2016 alkaen. Mediakasvatuksen näkökulmasta opetussuunnitelman perusteet näyttävät rohkaisevilta. Opetuksen arvoperustassa nostetaan esiin muun muassa monimediaisen tiedonvälityksen, globaalien tietoverkkojen ja sosiaalisen median merkitys lasten ja nuorten arvomaailmassa (POPS 2014, 13). Opetuksen tavoitteiksi perusteisiin on sisällytetty seitsemän osaamiskokonaisuutta, joita kehitetään kaikissa oppiaineissa. Mediakasvatukselle sisällöllisesti läheisin on monilukutaito (POPS 2014). Monilukutaito pohjautuu laaja-alaiseen käsitykseen tekstistä. Teksteillä voidaan tarkoittaa sanallisten, kuvallisten, auditiivisten, numeeristen ja kinesteettisten symbolijärjestelmien tai näiden yhdistelmien avulla ilmaistua tietoa. Monilukutaitoon kuuluvat taidot hankkia, yhdistää, muokata, tuottaa, esittää ja arvioida tietoa eri muodoissa, ympäristöissä sekä välinein (POPS 2014, 21). Monilukutaito yhdistyy tavoitteidensa puolesta myös laajemmin maailman ja sen kulttuurisen moninaisuuden ymmärtämiseen. Monilukutaito liittyy tekstien tulkitsemiseen ja tuottamiseen puhutussa, kirjoitetussa, audiovisuaalisessa tai digitaalisessa muodossa. 
Mediakasvatuksen rooli ei rajaudu opetussuunnitelmien perusteissa monilukutaitoon. Tieto- ja viestintäteknologinen (TVT) osaaminen on perusteissa määritelty kansalaistaidoksi. Teknisen osaamisen korostamista kuvaa hyvin se, että TVT on perusteissa ainoa kansalaistaidoksi määritelty osaamisalue. Osaamiskokonaisuuteen kuuluvat niin sisällöllinen osaaminen, erilaisten taitojen kehittäminen sekä TVT:n merkityksen pohtiminen osana ihmisten arkea, yhteiskuntaa, vuorovaikutusta ja vaikuttamista. Lisäksi oppilaita ohjataan ymmärtämään TVT:n käyttö- ja toimintaperiaatteita, käsitteitä sekä kehittämään TVT-taitojaan. Oppilaita opetetaan käyttämään tieto- ja viestintäteknologiaa tiedonhallinnassa sekä luovassa ja tutkivassa työskentelyssä. Oppilaat harjoittelevat lisäksi TVT:n käyttämistä myös vuorovaikutuksessa ja verkostoitumisessa. (POPS 2014, 21.)

Vaikka medialukutaito määritellään kuuluvaksi monilukutaidon kokonaisuuteen, kriittiseen medialukutaitoon (ks. esim. Herkman 2007) linkittyvä vaikuttaminen korostuu opetussuunnitelmien perusteissa osallistumisen, vaikuttamisen ja kestävän tulevaisuuden rakentamisen osaamiskokonaisuudessa (POPS 2014, 23). Sen tavoitteissa todetaan, että oppilaat oppivat arvioimaan median vaikutuksia ja käyttämään sen mahdollisuuksia. Maailman ymmärtämiseen ja aktiiviseen osallistumiseen liittyy myös kulttuurisen osaamisen, vuorovaikuttamisen ja ilmaisun osaamiskokonaisuus (POPS 2014, 19). Sen mukaan oppilaita ohjataan näkemään kulttuurinen moninaisuus myönteisenä voimavarana, tunnistamaan, miten media muokkaa kulttuuria ja pohtimaan asioita, joita ei voida ihmisoikeuksien vastaisina hyväksyä. Osaamiskokonaisuuteen sisältyy siis olennaisesti median roolin ja vaikutusten pohtimisen lisäksi myös ihmisoikeuksien kunnioittaminen.

Uusissa opetussuunnitelman perusteissa medialukutaidon sisällöissä painottuu aiempaa vahvemmin tulkinnan ohella tuottaminen. Kauppisen (2010, 223) mukaan opetussuunnitelmat ovat aiemmin ohjanneet lähinnä erilaisten mediatekstien vastaanottoon, jolloin vähemmälle ovat jääneet kriittiseen ja kulttuuriseen mediakasvatukseen kuuluva oma tekeminen, käyttö ja merkityksenanto. Näin ollen eri vuosikymmeninä koulunsa käyneillä suomalaisilla on mahdollisesti keskenään hyvin erilainen käsitys mediasta ja medialukutaidosta, sikäli kun ovat mediaan liittyvää opetusta ylipäänsä saaneet.

Suomessa kirjastoilla on nähty olevan iso rooli erityisesti sivistyksen ja saavutettavuuden näkökulmista. Kirjasto on kansalaisten peruspalvelu, jonka rooli mediakasvatuksessa on laajalti tunnustettu. Kirjastopolitiikassa 2015 (OPM 2009) otetaan huomioon, että eri-ikäiset ihmiset etsivät yhä enemmän ei-muodollisia tapoja oppia ja, että kirjastoista haetaan opastusta kansalais- ja tietoyhteiskuntataitoihin. Politiikan tavoitteissa todetaan, että kirjastojen ansiosta kansalaisten tasavertaisuus verkkopalveluiden käytössä paranee ja lasten ja nuorten perinteisen lukutaidon lisäksi media- ja informaatiolukutaito paranevat (Kirjastopolitiikka 2015, 30-31). Kirjastopolitiikka siis tiedostaa kirjaston merkityksen eri ikäryhmille. Kohderyhmiä määriteltäessä kuitenkin todetaan, että kirjastot tukevat lasten ja nuorten medialukutaidon kehittymistä. Samalla lisätään, että yleiset kirjastot tukevat toiminnallaan lasten ja opiskelijoiden tiedonhallinta- ja medialukutaitojen kehittymistä (OPM 2009, 26). Poikkeuksen kohderyhmään tekevät tässä tapauksessa siis opiskelijat. Ottaen huomioon, että moni aikuisista kehittäisi mielellään mediataitoja muodollisen koulutuksen sijaan itsekseen tai perheen tai ystävien kesken (Ofcom 2006), ei aikuisten rajaaminen medialukutaidon kehittämisen ulkopuolelle kirjastopolitiikassa vaikuta luontevalta.

Lapsi- ja nuorisopolitiikan kehittämisohjelmassa 2012-2015 yhtenä strategisena tavoitteena on lasten ja nuorten kasvaminen aktiivisiksi ja yhteisvastuuta kantaviksi kansalaisiksi. Kehittämisohjelmassa huomioidaan mielipiteen ilmaisun ja vaikuttamisen keinojen muutos esimerkiksi sosiaalisen median myötä. Samalla korostetaan tarvetta kehittää sellaisia tekemisen tapoja, joilla vahvistetaan nuorten resursseja, kykyjä, keinoja sekä motivaatiota vaikuttaa niin paikallisiin ja valtakunnallisiin kuin maailmanlaajuisiinkin asioihin. (OKM 2012b, 14.) Merkittävää tavoitteessa on vaikuttamisen keinojen vahvistamisen lisäksi motivaa- 
tion esiin nostaminen. Vaikka keinoja vaikuttamiseen olisi, täytyy olla myös halu toimia ja hyödyntää mahdollisuuksia.

Lapsi- ja nuorisopolitiikan kehittämisohjelmassa tuodaan esiin laaja-alaisten lukutaitojen merkitys sekä mediakasvatuksen rooli mediakriittisyyden edistämisessä. Tietoyhteiskuntaan osallistumisen tasapuolisuuden näkökulmasta kehittämisohjelmassa todetaan, että nuorten olisi myös hyvä tutustua avoimen lähdekoodin ohjelmistoihin ja käyttöliittymiin (OKM 2012b, 15). Osallisuutta tuetaan pyrkimällä takaamaan jokaiselle lapselle ja nuorelle perusedellytykset tietoyhteiskunnassa toimimiselle. Opiskelijoiden ja opettajien tietoteknistä osaamista kehitetään. Nuorisotyön määrärahoista myös tuetaan mediakeskusten perustamista sekä mediakasvatushankkeita. Myös verkkomedia- ja verkkonuorisotyön tukeminen nostetaan toimenpiteissä esiin. Ohjelmassa todetaan, että opetus- ja kulttuuriministeriö toteuttaa kehittämisohjelman lasten ja nuorten monipuolisen lukutaidon kehittämiseksi. (OKM 2012b, 18.)

Mediakasvatus näkyy oleellisesti myös Audiovisuaalinen kulttuuri digitaalisessa ympäristössä -linjauksissa (OKM 2012a). Linjausten tavoitteena on muun muassa monipuolinen ja runsas audiovisuaalinen kulttuuri sekä parantunut medialukutaito. Taustalla linjauksissa on digitaalisen ympäristön kehittyminen, joka puolestaan on korostanut mediakasvatuksen, medialukutaidon ja elokuvakasvatuksen merkitystä. (OKM 2012a, 12.) Linjauksissa nostetaan mielenkiintoisesti esiin mediakasvatuksen merkitys hyvinvointia lisäävänä tekijänä digitaalisessa ajassa. Medialukutaito liitetään maailman hahmottamiseen ja se koostuu linjauksissa audiovisuaalisten sisältöjen vastaanottamisesta, ymmärtämisestä sekä tuottamisesta. Huomioitavaa on myös, että mediakasvatuksella tuetaan linjauksissa (OKM 2012a, 55) laaja-alaisen lukutaidon myötä lasten ja nuorten elämisen hallinnan taitoja.

Vuonna 2013 OKM laati laajassa toimialayhteistyössä kulttuuripoliittiset suuntaviivat hyvän medialukutaidon edistämiseksi vuosille 2013-2016 (OKM 2013a). Suuntaviivoissa medialukutaito liitetään erityisesti osallisuuteen, kansalaisena toimimiseen, kriittisyyteen, luovuuteen ja itsensä ilmaisemi- seen. Näkökulma on vahvasti lasten ja nuorten medialukutaidossa ja arvopohjana toimii YKn Lapsen oikeuksien sopimus. Yleisesti visiona todetaan myös, että "Suomesta kehittyy yhteiskunta, jossa medialukutaitoa arvostetaan ja medialukutaidon merkitys ymmärretään yhä paremmin -- yhteiskunta panostaa nykyistä vahvemmin mediakasvatukseen" (OKM 2013a, 24). Linjauksien tavoitteina on lapsi- ja nuorisolähtöinen arjen mediakasvatus, mediakasvatuksen vakiintumista tukevien rakenteiden kehittäminen, mediakasvatustoimijoiden profiloitumisen ja kumppanuuksien vahvistuminen sekä Suomen aktiivinen globaali toiminta mediakasvatuksessa. Vaikka esimerkiksi rakenteellinen vakiinnuttaminen ja kumppanuudet todennäköisesti hyödyttävät kaikenlaista mediakasvatusta, huomionarvoista on, että konkreettiset toimenpiteet ja tavoitteet rajaavat aikuiset linjausten ulkopuolelle, kasvattajan roolia lukuun ottamatta.

\section{POHDINTA}

Tarkastelemiemme asiakirjojen valossa näyttää siltä, että suomalaisten lasten ja nuorten medialukutaidon kehittämiseen on vahva halu opetus-, kulttuuri- ja nuorisosektoreilla. Mikäli opetussuunnitelman perusteiden ja muiden linjausten tavoitteet siirtyvät käytäntöön, tulevaisuuden nuoret aikuiset saavat valmiudet hyödyntää medialukutaitoaan niin yksityis-, julkisessa kuin työelämässäkin. Haluamme kuitenkin pitää yllä kysymystä siitä, kuinka aikuiset huomioidaan mediakasvatussuunnitelmissa. Vaikka mediakasvatus määritelmällisesti kattaa linjauksissa koko väestön, jäävät aikuiset konkreettisten toimenpiteiden osalta lasten ja nuorten varjoon. Samaan tapaan esimerkiksi Hakkarainen ym. $(2009,47)$ ovat todenneet, että käytännön toiminta ja tutkimus kohdistuu mediakasvatuksessa ennen kaikkea lapsiin ja nuoriin, ikääntyneiden jäädessä varjoon. Miten varmistetaan eri-ikäisten kansalaisten tasa-arvoiset mahdollisuudet mediataitojen oppimiseen ja kehittämiseen? Tämän päivän kaksikymppinen ei pääse osalliseksi uuden opetussuunnitelman mediakasvatuksellisista lupauksista, eikä kolmekymppinen osallistavasta nuorisotyöstä, mutta heillä on yhteiskuntamme odotusten mukaisesti vielä vuosikymmenten mittainen työura edessään, ja keskimäärin parikymmentä 
vuotta sitäkin enemmän elinaikaa odotettavissa kansalaisina.

Vaikka tässä katsauksessa tarkasteltu aineisto ei ole kattava katsaus suomalaista mediakasvatusta ohjaaviin linjauksiin, antaa se selkeän viitteen siitä, kuinka mediakasvatuksen sisältöjä kehitetään laajasti niin koulutuksen, kirjastojen, lapsi- ja nuorisopolitiikan kuin audiovisuaalisen kulttuurin aloilla. Mediakasvatuksen ja medialukutaidon sisällöt kytkeytyvät kansalaisuuden ja yhteiskunnan eri ulottuvuuksiin. Näkökulmien ja sisältöjen moninaisuus voi olla myös haaste, mikäli määritelmät jäävät liian yleisiksi tai antavat turhan laajan tulkintamahdollisuuden. Vaikka mediakasvatuksen ja medialukutaidon sisältöjä ei tule selkeyden nimissä rankasti yksipuolistaa, käsitteellinen keskustelu mediakasvatuksen alalla on tärkeää.

Miten aikuisten medialukutaitoa sitten voitaisiin kansallisesti edistää? Valtiollisia linjauksia ja kasvatustavoitteita leimaa tavallisesti hallinnan varjo, sillä valtiolliset toimenpiteet pyrkivät "ideaalikansalaisen" kasvattamiseen. Instituutiot pyrkivät yleensä kriittisesti ajateltuna ennemmin säilymään kuin uudistumaan. Esimerkiksi lapsuuden konstruointia suomalaisissa koulutuspoliittisissa mediakasvatusasiakirjoissa tutkivan Niina Uusitalon (2013) mukaan medialukutaito nähdään asiakirjoissa patenttiratkaisuna, joka johdattaa digitaalisen ajan kasvavat populaatiot "oikeanlaiseen" asemaan ja kansalaisuuteen. Ihmisiä - etenkin lapsia - käsitellään kehitettävinä potentiaaleina sen sijaan, että heidän olemassa oleva osaamisensa tunnustettaisiin. Hallitsemisen ja holhouksen diskurssit ovat lastenkin kohdalla kritiikille alttiita, ja aikuisten kohdalla ongelma on vielä ilmeisempi. Millaisia ovat aikuisten mediakasvatuksen tavoitteet ja keinot, ja kuka haluaa aikuisten osalta vetää ylleen kasvattajan viitan? Esimerkiksi Mika Mustikkamäen (2014) mukaan kirjastoissa on vierastettu "kasvatus"-käsitettä. Tämä huomio tukee tarvetta kasvatuksen ja kasvamisen kysymysten vahvemmalle esiin nostamiselle myös perinteisesti nähtyjen kasvatusinstituutioiden ulkopuolella. Tutkijoiden huomio aikuisten medialukutaitoa ja mediakasvatusta koskevan tutkimuksen vähyydestä on syytä muistaa pohdittaessa keinoja medialukutaidon edistämiseen.
Nähdäksemme olisi hyvä aloittaa tietoisuuden lisäämisestä. Suomessa on tehty monenlaisia koonteja lasten ja nuorten medialukutaidon edistämisen parhaista käytännöistä, mutta aikuisten osalta vastaavia emme ole kohdanneet. Tämä siitä huolimatta, että ainakin soveltaen aikuisille käyttökelpoista materiaalia ja toimintaa tuottavat julkisista toimijoista esimerkiksi kirjastot, museot, oppilaitokset, Yleisradio, Kilpailu- ja kuluttajavirasto sekä oma työpaikkamme Kansallinen audiovisuaalinen instituutti. Lukuisat kolmannen sektorin toimijat ja kansalaisten vapaat verkostot sosiaalisessa mediassa ovat myös erittäin aktiivisia. Tämä toiminta jää kuitenkin medianäkyvyydessä lapsille ja nuorille tarjottavien mahdollisuuksien ja mediapaniikkisen suojelupuheen jalkoihin. Lisäksi liian usein aikuisten olemassa olevat mediataidot unohtuvat ja media-aiheet käsitellään julkisuudessa puutteiden kautta: poliitikkojen viestikohuina tai kansalaisten median välityksellä tekeminä rikoksina tai typeryyksinä. Vanhemmuuteen ja mediaan liittyvä uutisointi korostaa sekin vahvasti vanhempien tietämättömyyttä ja riittämättömyyttä (Alajärvi 2015).

Pidämmekin todennäköisenä, että kansalaiset eivät juuri tunne aikuisten medialukutaidon olemassa olevia kehittymisen ja oppimisen mahdollisuuksia. Nykyistä laajempi ja systemaattisempi hyvien käytäntöjen kokoaminen, jakaminen ja niistä tiedottaminen sijoittaisi aikuisten medialukutaidon vahvemmin osaksi elinikäistä oppimista. Näin voitaisiin kannustaa aikuisväestöä kehittämään mediaosaamistaan omista lähtökohdistaan ja nykyistä laajemmin itsenäisesti, ryhmissä tai vakiintuneiden instituutioiden piirissä. Tavoitteena tulisi olla tasa-arvoisten mahdollisuuksien tarjoaminen itsensä kehittämiseen, yhteiskuntaan osallistumiseen sekä sen uudistamiseen.

\author{
Saara Pääjärvi \\ Erityisasiantuntija \\ Kansallinen audiovisuaalinen instituutti (KAVI) \\ Lauri Palsa \\ Projektitutkija \\ Kansallinen audiovisuaalinen instituutti (KAVI)
}


Alajärvi, J. (2015). "Kyllä vanhempien pitäisi tietää, millä sivustoilla lapsi netissä käy". Representaatiotutkimus lasten netinkäytön uutisoinnista Lapin Kansassa 2014-2015. Pro gradu -työ. Rovaniemi: Lapin yliopisto.

Dunas, J. (2013). Media and Information Literacy in the Nordic Countries. Saatavilla www-aineistona: http:// www.statensmedierad.se/upload/_pdf/Overview\%20 MIL\%20in\%20Nordic\%20Countries.pdf (tarkistettu 3.9.2015)

EAVI (2009). Study on Assessment Criteria for Media Literacy Levels: A comprehensive view of the concept of media literacy and an understanding of how media literacy levels in Europe should be assessed. Bryssel: EAVI.

Euroopan digitaalistrategia (2010). Komission tiedonanto Euroopan parlamentille, neuvostolle, Euroopan talous- ja sosiaalikomitealle ja alueiden komitealle. KOM(2010)245 lopullinen. Euroopan komissio.

Euroopan komission suositus medialukutaidosta digitaalisessa ympäristössä: kohti kilpailukykyisempää audiovisuaali- ja sisältöteollisuutta ja osallistavampaa osaamisyhteiskuntaa (2009/625/EY) EUVL, L 227/9, 29.8.2009.

Hakkarainen, P., Hyvönen, P., Luksua, T. \& Leinonen, O. (2009). Ikääntyneet mukaan mediakasvatukseen. Aikuiskasvatus 29(1), 44-51.

Herkman, J. (2007). Kriittinen mediakasvatus. Tampere: Vastapaino.

Kauppinen, M. (2010). Lukemisen Linjaukset: Lukutaito ja sen opetus perusopetus äidinkielen ja kirjallisuuden opetussuunnitelmissa. Jyväskylä: Jyväskylän yliopisto.

Kotilainen, S. (toim.) (2011). Lasten mediabarometri 2010. 0-8-vuotiaiden mediankäyttö Suomessa. Mediakasvatusseuran julkaisuja 1/2011.

Kotilainen, S. \& Sintonen, S. (2005). Mediakasvatus 2005. Kansalliset kehittämistarpeet. Oikeusministeriön julkaisuja 2002-2009, 2:2005.

Kupiainen, R., Sintonen, S. \& Suoranta, J. (2007). Suomalaisen mediakasvatuksen vuosikymmenet. Teoksessa Kynäslahti, H., Kupiainen, R. \& Lehtonen, M. (toim.) Näkökulmia mediakasvatukseen. Helsinki: Mediakasvatusseura, 3-26.
Lundvall, A. \& Andersson, J. (2012). Katsaus mediakasvatuksen toimijoihin 2012. Helsinki: Mediakasvatusseura.

Martens, H. (2010). Evaluating Media Literacy Education: Concepts, Theories and Future Directions. Journal of Media Literacy Education 2(1), $1-22$.

Mustikkamäki, M. (2014). Mediakasvatus yleisissä kirjastoissa: suosituksia ja suuntaviivoja.Suomen Kirjastoseura. Saatavilla www-osoitteesta: http:// suomenkirjastoseura.fi/files/Mediakasvatus/ mediakasvatus_koko\%20julkaisu\%20netiss $\% 20$ 24\%202\%202014.pdf (tarkistettu 3.9.2015)

Niinistö, H. (2008). Mediakasvatus uutena kansansivistyksenä: Tapaus Mediamuffinssi. Teoksessa Poikela, S. \& Ylitapio-Mäntylä, 0. (toim.) Aikuiskasvatus kevytyhteisöjen ajassa. Rovaniemi: Lapin yliopiston kustannus, 37-46.

Ofcom (2006). Media Literacy Audit: Report on adult media literacy. Saatavilla www-osoitteessa: http:// stakeholders.ofcom.org.uk/binaries/research/ media-literacy/media-lit-2010/medialit_audit.pdf (tarkistettu 3.9.2015)

OKM (2013a). Hyvä medialukutaito; Suuntaviivat 20132016. Helsinki: Opetus- ja kulttuuriministeriö. Saatavilla www-osoitteessa: http://www.minedu. fi/export/sites/default/OPM/Julkaisut/2013/liitteet/ OKM11.pdf?lang=fi (tarkistettu 3.9.2015)

OKM (2013b). Mediakasvatus kuntien varhaiskasvatuksessa. Helsinki: Opetus- ja kulttuuriministeriö. Saatavilla www-osoitteessa: http://www.minedu.fi/export/sites/default/ OPM/Julkaisut/2013/liitteet/okm10.pdf?lang=en (tarkistettu 3.9.2015)

OKM (2012a). Audiovisuaalinen kulttuuri digitaalisessa ympäristössä: Poliittiset linjaukset. Helsinki: Opetusja kulttuuriministeriö. Saatavilla www-osoitteessa: http://www.minedu.fi/export/sites/default/OPM/ Julkaisut/2012/liitteet/okm31.pdf (tarkistettu 3.9.2015]

OKM (2012b). Lapsi- ja nuorisopolitiikan kehittämisohjelma 2012-2015. Helsinki: Opetus- ja kulttuuriministeriö. Saatavilla www-osoitteessa: http://www.minedu.fi/OPM/Julkaisut/2012/liitteet/ OKM06.pdf (tarkistettu 3.9.2015) 
OPM (2009). Opetusministeriön kirjastopolitiikka 2015 : Yleiset kirjastot. Kansalliset strategiset painoalueet. Helsinki: Opetusministeriö. Saatavilla wwwosoitteesta: http://www.minedu.fi/export/sites/ default/OPM/Julkaisut/2009/liitteet/opm32. pdf?lang=en (tarkistettu 3.9.2015)

Palsa, L., Pääjärvi, S., Tossavainen, T. \& Pekkala, L. (2014). Mediakasvatushankkeet 2008-2013. Helsinki: Kansallinen audiovisuaalinen instituutti. Saatavilla www-osoitteessa: https://kavi.fi/ sites/default/files/documents/kavi_selvitys_ mediakasvatushankkeet_2009-2013.pdf (tarkistettu 3.9.2015)

Pekkala, L., Pääjärvi, S., Palsa, L., Korva, S. \& Löfgren, A. (2013). Katsaus suomalaisen mediakasvatustutkimuksen kenttään. Selvitys kotimaisesta mediakasvatukseen liittyvästä tutkimuksesta erityisesti opinnäytteiden ja journaaliartikkeleiden osalta pääosin vuosien 2007-2012 ajalta. Helsinki: Mediakasvatus- ja kuvaohjelmakeskus.

Potter, W. J. (2010). The state of media literacy. Journal of Broadcasting \& Electronic Media 54(4), 675-696.

Potter, W. J. (2013). Review of Literature on Media Literacy. Sociology Compass 7(6), 417-435.

Pääjärvi, S. (2012). Lasten mediabarometri 2011 : 7-11-vuotiaiden lasten mediankäyttö ja kokemukset mediakasvatuksesta. Helsinki: Mediakasvatusseura.

Ratkaisujen Suomi. Neuvottelutulos strategisesta hallitusohjelmasta (2015). Saatavilla wwwosoitteessa: http://www.keskusta.fi/loader. aspx?id=c3374414-88d8-4b64-87a4-27faab2880c5 (tarkistettu 3.9.2015)

Sivistysvaliokunnan mietintö 2/2013. Hallituksen esitys eduskunnalle laiksi Kansallisesta audiovisuaalisesta arkistosta annetun lain muuttamisesta sekä eräiksi siihen liittyviksi laeiksi. Saatavilla www-osoitteessa: https://www.eduskunta.fi/FI/vaski/mietinto/ Documents/sivm_2+2013.pdf (tarkistettu 3.9.2015)

Suoninen, A. (2014). Lasten mediabarometri 2013: 0-8-vuotiaiden mediankäyttö ja sen muutokset vuodesta 2010. Helsinki: Nuorisotutkimusseura.

Suoninen, A. (2013). Lasten mediabarometri 2012: 10-12-vuotiaiden tyttöjen ja poikien mediankäyttö. Helsinki: Nuorisotutkimusseura.
Suoranta, J. (2006). Aikuisten medialukutaitoa selvitettiin Isossa-Britanniassa, entä Suomessa? Aikuiskasvatus 26(3), 248-250.

Uusitalo, N. (2013). Deconstructing ideas of childhood and youth in media education policy. Konferenssipaperi. Oslo: Nordmedia2013.

Varis, T. (2002). Isovanhempana digitaalisessa ajassa. Teoksessa Sintonen, S. (toim.) Median sylissä Kirjoituksia lasten mediakasvatuksesta. Helsinki: Finn Lectura Oy.

Vesterinen, O. (2011). Media Education in the Finnish School System : A Conceptual Analysis of the Subject Didactic Dimension of Media Education. Helsinki: Helsingin yliopisto.

Vilmilä, F. (2015). Media + lapsi + kasvatus: Mediakasvatuksen tutkimuksellinen kehittäminen Helsinki: Nuorisotutkimusseura. 